\title{
The governing of the self/the self-governing self: Multi-rater/source feedback and practices 1940-2011
}

\author{
Rory Slater and Adrian Coyle \\ School of Psychology, University of Surrey, UK
}

Address for correspondence: Rory Slater, School of Psychology, University of Surrey, Guildford, Surrey GU2 7XH, UK. Tel. +44 (0)1483 686870. Email R.Slater@surrey.ac.uk

Rory Slater is a $\mathrm{PhD}$ candidate in the School of Psychology at the University of Surrey. His $\mathrm{PhD}$ involves a three-part qualitative analysis that seeks critically to consider the post-capitalist democratisation of the workplace and the complicit involvement of psychological knowledge and expertise in contemporary programmes of government at work.

Adrian Coyle is Senior Lecturer and Course Director for the MSc in Social Psychology in the School of Psychology at the University of Surrey. His research and publications have addressed a range of topics, principally psychological issues in religion and spirituality, identity, bereavement and sexuality. The vast majority of his research is qualitative, employing a range of methods. With Evanthia Lyons, he was editor of Analysing Qualitative Data in Psychology (Sage, 2007).

\section{ACKNOWLEDGEMENTS}

We wish to acknowledge the invaluable contribution of our late colleague, Lynne Millward, to this work. As a Social and Occupational Psychologist at the University of Surrey, Lynne ensured the work was contextually informed and provided much encouragement. We would also like to express our gratitude to Peter Hegarty of the University of Surrey's School of Psychology for helping us to develop the ideas presented in this paper. Finally we wish to offer sincere thanks to the anonymous reviewers of the paper for their constructive input which has contributed greatly to the refinement of our ideas: their responses to our work allowed us to experience the academic review process at its best.

The full reference for the published version of this article is: Slater, R., \& Coyle, A. (2014). The governing of the self/the self-governing self: Multirater/source feedback and practices 1940-2011. Theory \& Psychology, 24(2), 233-255. DOI: $10.1177 / 0959354313520087$ 


\title{
The governing of the self/the self-governing self: Multi-rater/source
}

\section{feedback and practices 1940-2011}

\begin{abstract}
The present paper argues for a more critical contextualisation of multi-rater/source feedback mechanisms applying Foucault's conceptual template of technologies of objectification and subjectivity/self, as they relate to a mode of "self" government that is intricately entwined with psychological knowledge and expertise. An in-depth genealogical analysis is presented that traces the genesis of two prominent forms of multi-rater/source feedback mechanisms between 1940 and 2011: the educational innovation of the T-group and the contemporary human resource practice of 360-degree feedback. We conclude that such practices have functioned to enfold individuals within relations of power and signification that impact upon individual selfgovernance, subjectivity, and identity. As such, the application of 360-degree feedback within contemporary organisational models is emblematic of a programme of government that relies for its effectiveness on the self-regulatory and self-developing capacities of the individual at work.
\end{abstract}

\section{Key words}

360-degree feedback; psychologised-self; self-government; subjectivity; T-groups 
Current organisational thought holds that employee "self" development is best facilitated when feedback from multiple sources (such as subordinates, peers, bosses, customers, and seleves) is provided by the organisation and internalized by the individual. This has particularly been the case with reference to the modern multi-rater/source feedback mechanism known as "360degree feedback".

This term (hereby referred to simply as "360") was originally coined by Edwards and Ewen in 1996 as a response to participant-based feedback that became a trademark of the company TEAMS Inc. According to Bracken, Timmereck, and Church (2001), more than one-third of companies in the United States use multi-rater/source observation and feedback mechanisms. More recently, Mylett (2009) has reported that some ninety per cent of all Fortune 500 firms (the Fortune 500 is an annual list compiled and published by Fortune magazine that ranks the top 500 public corporations according to their gross revenue in the United States) now use some form of multi-rater/source feedback to appraise and/or develop their workforce.

In light of its burgeoning popularity, it is somewhat perplexing that little, if any, critical consideration has been afforded to issues of power as manifest within the contemporary mechanism and practice of 360 at work. Furthermore, the majority of contemporary literature surrounding 360 and other multi-rater/source feedback mechanisms has yet to broach critical concerns regarding how this modern appraisal and development mechanism might impact on individual subjectification and self-governance at work - that is, the micro-politics of the self and subjectivity.

In what follows, we argue for a more critical contextualisation of multi-rater/source feedback mechanisms than has previously been afforded and suggest that such practices are exemplary of what Foucault referred to as apparatuses of power that juxtapose technologies of the object and objectification (the individualising and totalising effects of observation and documentation) with those of subjectivity and the self (the relationship the individual forms with themselves or the “self"). 
Hook (2007, p.31) has defined subjectification as, "the promotion and elaboration of a thoroughly individualised set of knowledges about the singular subject who is effectively normalised and psychologised as a result". In this sense subjection is achieved through the enfolding of subjects into reflexive patterns of self-awareness and self-production by way of what Foucault (1988) and Rose (1996, 1999 see also Hook, 2007) referred to as technologies/techniques of the self.

By considering the forms that multi-rater/source feedback mechanisms have assumed over historical time, we present two prominent cases for analysis. The first is rooted in the work of Gestalt psychologist, Kurt Lewin, and the social movement that became known as the laboratory method. Historical links are made between the laboratory methods flagship mode of education, the training or T-group, and the contemporary employee appraisal and development practice of 360.

Both of these multi-rater/source feedback mechanisms can be seen as having emerged out of historically relative attempts to combine disciplinary practices with psychological knowledge and expertise to empower individuals to manage their own risks and to modify their own behaviour for the greater good - that is, to conduct their own conduct and become self-regulating and selfdeveloping. We contend that both the T-group and 360 are representative of the "real-world" application of those (disciplinary) technologies and techniques of objection and subjection and as such function to reify and ratify a specific programme of government aimed at guiding and shaping the actions and conduct of the subject at work - what Michel Foucault termed "governmentality". These techniques/technologies have functioned over historical time to "empower" individuals that are both willing and capable of morally and ethically governing themselves under the rubric of self-development.

The concept of governmentality extends Foucault's earlier work on (disciplinary) bio-power that saw the subject as fervently oppressed by the individualising and totalising effects of authority (McNay, 1994). Conversely, within the framework of governmentality, individuals are 
viewed as free subjects who, through various technologies/techniques of subjectivity/self, become actively involved in internal and voluntary relations of rule insofar as they act upon themselves in particular ways within the confines of certain subject-positions in discourse (Cruikshank, 1999). Government and the rationalities thereof not only encompass relations of power and authority but also those of the self and identity insomuch as before something can be governed it must first become known in great detail (Rose, 1996, 1999; Townley, 1993).

In light of this contention, we propose that the current multi-rater/source feedback mechanism known as 360 constitutes a combined technical assembly of means of objection and subjection built into the very social fabric of the modern organisation. The individual "in" the organisation is then being transformed into a self-regulating and self-developing subject through a precise kind of social architecture (that is, the way in which 360 organises individuals in space) that operates not only, to observe the individual at work in such a way as to know them, "provide a hold on their conduct... to make it possible to know them, to alter them" (Foucault, 1977, p. 172) but also, to allow individuals to better know themselves, to understand their own behaviour and, as a result, alter it.

Moreover, this process is intricately intertwined with and, as such, partially obscured by contemporary theories, methods, practices and regimes of knowledge regarding the “psychologised self". The suffusion of psychological knowledge and expertise into work and organisational life has brought a distinctly human element to the capitalist endeavour that has functioned to facilitate the emergence of a version of the "self" that can become known, developed and, as a result, governed.

What both Rose $(1996,1999)$ and Hook $(2007)$ have referred to as "the psy-disciplines" have become complicit in contemporary programmes of self-government at work. Hook (2007) articulates this particularly well by stressing that in order for power to exact a longer lasting effect on the body, to change it and to alter it on a more permanent basis, it must engender within the individual what he calls a "soul-effect" - that is, the spawning of central essence or inner 
psychological universe akin to an identity, personality, soul or self for example. He goes on to suggest that it is only when the individual takes up the state of having a personality or identity etc; that the effects of power can penetrate much more deeply than the flesh and affect individual subjectivity.

Dean (2010, p. 44) has noted that programmes of government and the forms of identity that presuppose them, "elicit, promote, facilitate, foster and attribute various capacities, qualities and statuses to particular agents". In this sense government is very much a double-edged sword insofar as certain regimes of power/knowledge may indeed promote new possibilities for action, capacities, qualities and statuses such as freedom, autonomy and empowerment (as is the case with liberal democracy to varying degrees). In so doing they provide, those multifarious forms of authority with new possibilities for the control and government of individuals in space.

The extent to which the individual comes to actively internalise and take on the identity/identities on offer to them in discourse (what we understand as subjectivization) is however, ultimately dependent on the real world application of what Foucault referred to as technologies and techniques of the self and subjectification. These techniques cut "across symbolic systems while using them" (Foucault, 1988, p. 368) allowing individuals to "effect by their own means or with the help of others a number of operations on their own bodies and souls, thoughts, conduct and way of being" (Foucault, 1988, p. 18). This position is echoed by Rose (1999, p. xx) who stresses that "Relations of the self are not merely a matter of language, but of truths, norms, techniques - techniques of the self': of which multi-source observation and feedback mechanisms and practices are, we propose, an example.

\section{The contemporary shaping and re-shaping of the self at work}

Although numerous authors have sought to apply and in some cases assess a number of Foucault's theoretical conceptualizations such as governmentality, discourse and 
power/knowledge within the economic domain (see for example Du Gay, 1996, 1997; Knights \& Willmott, 1989; Miller \& Rose, 1991; Mumby \& Sthol, 1991; Townley, 1993, 1994; Willmott, 1993), very few have attended to the genesis of those technical assemblages that give effect to certain power formations and the programmes of government they function to reify and ratify within the social milieu of the day-to-day.

Notable exceptions however include the work of Hollway (1991) who provides an illuminating account of work psychology from the perspective of the historical regulation of work and the workforce. This endeavour is of particular relevance here as it traces how the "psychology" of work has been complicit in the emergence of the practices of self-organization and self-discipline within modernity over historical time.

The genealogical methodology of Michel Foucault offers an object of enquiry that traverses the much-debated macro/micro-level analytic distinction regarding the organisation of individuals within society as it focuses on the how of power - that is to say, the assemblages of human technologies that locate and enable individuals to recognise themselves as certain types of subjects at different periods over historical time (Rose, 1996, 1999).

By virtue of its anti-essentialist epistemology the framework of genealogy then juxtaposes the concepts of power and the body by locating the human body itself at the very nucleus of a series of historical conflicts between competing power formations (McNay, 1994). From this perspective historically relative power-formations act not only "on" the body but also "through" it in such a way that the human subject becomes the site for a series of historical problematisations surrounding the "truth" about what it "means" to be a man or a woman, sane or insane, heterosexual or homosexual etc., at given points over historical time.

In line with Hook and Howarth (2005 see also Hook, 2001a, 2005, 2007; Rose, 1996, 1999) we propose that a greater attention to those formative conditions of the subject's subjectivity (that is to say, subjectification) in terms of such factors as knowledge, materiality, power, the body, and in particular the historical provides a proposition toward a more critical social 
psychology of organisations and their internal politics that cannot be adequately grasped by attending to discourse as language or textuality alone. Such a focus within the domain of organisational theory then provides one with a crucial means of departing from the strict truth conditions of mainstream social and organisational science, and of addressing the ontological disparity that exists between those largely discursive analytic traditions that tend to overlook the material instances of power that work in conjunction with discourse.

This is apparent in considering discourse to be historically isolated and purely linguistic. Any suggestion that those many and varied forms of discourse analysis may function as a critical (political) project is effectively undermined. In short, limiting discourse analytic research to text, or rather talk as text, runs the risk of producing a version of the social world that is bereft of any material and/or historical grounding.

\section{The emergence of multi-rater/source feedback in the 1940s: The Laboratory Method}

The founders of the laboratory method, Kurt Lewin, Ronald Lippitt, Leland Bradford, Jack Gibb and Kenneth Benne, envisaged that the group itself could act as a bridge between the individual and society by serving two interrelated functions. The first was that the group could facilitate, "the re-education of the individual toward a greater integrity, greater understanding of himself and of the social conditions of his life, greater behavioural effectiveness in planning and achieving changes both in himself and in his social life" (Bradford, Gibb \& Benne, 1964, p. 5). Inherent within this belief was that people can learn to "use groups for individual rehabilitation and for the reconstruction of the social environment" (ibid., emphasis in original).

As a social movement that relied for its effectiveness on emergent social psychological theory and practice, the laboratory method was underpinned by the democratic belief that people hold the potential to work collectively in defining and solving the social problems they faced. This kind of active citizenship required individuals not only to participate enthusiastically in the 
politics of the liberal democratic societies in which they were embedded but also actively to develop social cohesion by reducing inter-group tension. It can be said therefore that, as an historical movement intent on improving human relations, the laboratory method sought to link educational methodology with social action in democratic societies with the aim of enhancing civil participation (Bradford et al., 1964).

This belief was accompanied by a deep-rooted conviction that heightened social and physical mobility, coupled with the technological advances that arose both during and after the Second World War, had placed an unprecedented pressure on individuals to change in order to meet the needs of a rapidly developing society with little or no support, educational or otherwise (Bradford et al., 1964). In the United States the period following the Second World War was one of great change and opportunity. In the wake of the devastation left by years of bloody conflict, nations laboured intensely to rebuild their infrastructures and economies. According to Bradford (1976) this post war period was a particularly exciting time for the behavioural sciences and those individuals who researched in its name. Prior to the 1940s the term "behavioural science" had made little impact upon a scientific community that, at the time, was dominated by the so called "harder" sciences. Attempts to apply psychologically-based knowledge to the study of real-world events and phenomena including the human condition itself were rare.

It was during this time of rapid global change that there emerged a growing interest in the active restoration of human relations generally and inter-group relations specifically for the purpose of national growth and success. Interest in the social side of enterprise also intensified in response to the work of Elton Mayo (1933) who contributed significantly to the development of the Human Relations movement that became based at the Tavistock Institute in London in the 1950s/1960s. Over a series of studies conducted between 1923 and 1932 at the Hawthorne works of the Western Electrical Company based in Chicago, in which Mayo was directly involved, it was suggested that informal group life affected individual productivity and motivation more than the characteristics of the labour process itself. 
The Human Relations paradigm itself focused primarily on interpersonal and group relations recognising their importance in the creation and maintenance of formal and informal work-based systems. As a social movement it was underpinned by Carl Rogers' Humanistic Phenomenology that stressed an alternative view of the individual as a whole paying particular attention to their immediate conscious experience and part this plays in determining an individual's perception of reality (Rogers, 1951).

The paradigmatic roots of laboratory training sought to combine an emergent humanistic psychology with the educational philosophy of John Dewey who himself held a deep-rooted conviction that democracy and hence democratic ideals should form the cornerstone of all interpersonal relations within society (Dewey, 1916). The laboratory method thus combined Dewey's educational philosophy with those democratic values that underpinned American society. Prior to the seminal insights born out of the infamous Connecticut workshop that took place at the State Teachers College in 1946. Lewin was recruited to the Massachusetts Institute of Technology (MIT) by professor-consultant and behavioural scientist, Douglas McGregor, where he founded the Research Centre for Group Dynamics (hereafter referred to as RCGD). As a young Jewish man who had lived and worked in Nazi Germany before the outbreak of the Second World War, Lewin was forced to leave Berlin and seek refuge in Britain before eventually settling in the United Sates in 1933. In 1939, he first made reference to group-dynamics, a branch of social psychological theory that conceived of the group as an entity in possession of its own unique dynamic and not merely the sum of the individuals who comprised it. Lewin believed that a reciprocal relationship existed between the individual and the group situation in which they were embedded - that is, the individual's personality and the social environment in which they exist (Minaham, 2006).

Early training laboratories tended to work primarily with heterogeneous groups of individuals, all of whom were involved in so-called helping professions and/or education. It was believed that these individuals were particularly well placed to operate as "change agents" insofar 
as they could apply what they had learnt (experientially) about the dynamics of small groups in order to help others deal more successfully with the social problems they faced. By analysing their own learning, individuals could effectively direct their efforts toward achieving a "selfidentity which is active, reflective, realistically optimistic and collaborative" (Bradford et al., 1964, p. 18-19).

\section{One serendipitous night in Bethel: The advent of the T-group}

Toward the latter part of the ninetieth century, American society remained firmly divided by class, ethnicity and race which proved something of a dilemma for a country seeking to foster social cohesion and civic participation among its citizens. Up until 1908, racial segregation remained prevalent as virtually all southern American states at the time marginalised African Americans through the deployment of discriminatory devices such as the poll tax and literary testing, all of which prevented many racial groups from exercising their democratic right to vote. As a result, this left them vulnerable to segregation and social and economic subjugation (Riser, 2006). Historian Richard McCormick (1991, p. 110) reported that, for southern African Americans, "the early 1900s brought nearly complete exclusion from politics, legal segregation of virtually all public and private facilities, and a sicking explosion of race riots and lynchings". This kind of racial tension echoed throughout American society and worked to hinder attempts at social cohesion, civic participation and trust between different racial and ethnic groups (Putnam, 2000).

The need for the cooperation between nations and the individuals that comprised them prompted the Connecticut Interracial Commission to approach the RCGD and the American Jewish Congress in an attempt to tackle racial discrimination with the aid of social-scientific theory and methodology (Lippitt, 1949). In 1946 Lewin, along with several of his associates from the RCGD, were approached by the Connecticut State inter-racial Commission and asked to 
conduct a series of learning exercises that would enable leaders to deal with this kind of racial and religious prejudice. A two-week programme was developed and implemented with the aid of Ronald Lippitt, who agreed to direct the programme, and Leyland Bradford and Kenneth Benne, both of whom agreed to take part in the project by acting as training staff (Lakin, 1972).

On the eve of the third day and seemingly by chance, several of the workshop members asked to sit in on one of the feedback meetings that took place between Lewin and his associates. As the session progressed, several of the visiting workshop members felt the need to express how they had been psychologically affected by staff interventions, with one woman actively disagreeing with the observer's interpretation of her behaviour. It is said that Lewin himself was particularly excited about this new information and began to document the workshop members' perception of the day's events (Bradford et al., 1964).

After discussions had ended, the three workshop members asked if they could attend the next reporting session, to which Lewin eagerly agreed. According to Bradford (1976), it soon became apparent to Lewin that the workshop members were more interested in the feedback they gained from the research observer regarding group interactions than they were in what happened during the workshop sessions. It was also noted that the observations discussed during these evening feedback sessions were having a significant impact on individual behaviour during the day workshops as members were actively changing their behaviour as a result of the hereand-now feedback they were receiving from the research observers.

It was the post-workshop feedback sessions that transpired which gave rise to a significant and powerful educational method for learning that used the here-and-now experiences of interpersonal interactions (that is, the group experience) as a basis for individual learning. The laboratory method itself was developed with the express intention of changing individual selfknowledge and behaviour through (self) learning (Bradford, 1974). As an action or rather experiential process, it sought to facilitate the generation of (self) knowledge through the giving and receiving of feedback from other group members. Individuals thus became sensitive to the 
impact of their own and others' behaviour on the group and its processes The laboratory programme was in effect a way of bringing individuals together to form a social system or rather a particular type of informal group situation that arranged them in such a way as to achieve a desired end, that being the (re)education of individuals (Argyris, 1964).

Before his untimely death in 1947, Lewin had secured funding from the United States Office of Naval Research and the National Education Association, and the first National Training Laboratory (NTL) human relations conference was held in a small town or cultural island in Bethel, Maine. Bethel thus became the regional site for NTL endeavours and the extensive research efforts that went into the development of the experiential laboratory method and the TGroup. The training staff at the NTL included Lewin's former associates, Bradford, Benne and Lippitt, all of whom operated under the direction of J. R. P. French. The first NTL workshop centred around the concept of basic skills training (BST) groups (which later became popularised as the T-Group) which sought to emphasise the development and practice of skills through the use of role-play and group discussions and feedback (Back, 1972).

The concept of feedback formed a core tenet of T-Group theory and practice: it was believed that in order for feedback to be effective it should be provided in the form of the here-and-now observations of other group members. It was this process of giving and receiving personallyrelevant (in situ) information, or rather feedback that facilitated the development of a knowledge about oneself and one's own behaviour which, according to Bradford et al. (1964), became an integral focus of the T-Group's experience and process as it incited and facilitated self-reflection.

We propose that by removing individuals from their social/organisational setting and placing them in what was effectively a human observatory in which group members scrutinized one another, the T-group functioned as a method for accumulating large amounts of personally relevant information that could be fed-back to individuals for the purpose of self-reflection and hence "self'-development. This is in itself is emblematic of the disciplinary management of prisoners within modernity insofar as for Foucault (1977) modern discipline and punishment 
began with the functional distribution of individuals "in space" such that they may be fixed both spatially and conceptually.

According to Foucault (1977), there are three primary methods through which this is achieved: enclosure, partitioning and ranking. Enclosure involves geographical and spatial separation as reflected in Foucault's analyses of the asylum, the hospital and the prison. The creators of the T-group actively attempted to isolate and enclose individuals within a so called "cultural island" away from the influences of the outside world (Sofer, 1972). Within the small town of Bethel each individual could participate in the T-group process in relative isolation while their inter-personal behaviour(s) could become known in great detail.

The organisation of individuals in this way functioned to fix them temporally, spatially and conceptually, allowing their in-group behaviour to be observed, classified, and as a result normalised - that is made visible, calculable and amenable to deliberation. This kind of social isolation accords with Foucault's (1977) "rule of functional sites" as Bethel became a "useful space" that juxtaposed the need for supervision with the isolation of the individual so as to disrupt the possibility of influential and/or problematic communications. Although T-group participants were not isolated as individuals, they were "removed" from the rest of society. This is apparent insofar as the kind of "group" produced by the T-group process consisted of individuals who were to be, in a sense, rehabilitated so that they might provoke similar changes within the societies, organisations and groups in which they were embedded.

The infinitely more subtle concept of partitioning (Foucault, 1977) can also been seen within the practice of the T-group insofar as, although subjects are "enclosed" and isolated from the outside world, they are brought together as a functional group geared toward the development of solidarity and community. On the face of it, this is seemingly at odds with Foucault's description of partitioning in which subjects are divided from each other to prevent the emergence of solidarity and community. Yet it could be argued that partitioning (albeit in a non-corporeal sense) formed an integral part of the T-group process insofar as each group member is 
individualised, made unique, and, as such, isolated as an object of scrutiny; as the nucleus of a functional narrative regarding the impact of their behaviour upon others. This kind of "linguistic partitioning" where each individual becomes the locus of a self-other narrative operates to externalise and individualise conduct and behaviour in such a way as to make it functional and usable for the purpose of development or on could say rehabilitation. In this sense the unity of the group is fragmented by the apparatuses of observation and judgment that the process employs.

Through acknowledging and discussing this "feedback", the individual themselves were placed at the very nucleus of a reformative narrative about the "self" in which they were actively involved. It was then through the juxtaposition individualising techniques and technologies of the object and objectivity and those of subjectivity and the self that T-group members were not only constituted and made subject to power/knowledge but also came to understand and act upon themselves as certain types of subjects within specific contexts. As Cruickshank (1999) adeptly points out in her critical analysis of the self-esteem movement, it is by way of turning the self into the subject of a personal narrative that individuals come to actively construct a self to act upon and to govern.

In its capacity as an educational method that promoted self-reflection through the giving and receiving of feedback, the T-group also incorporated a uniquely confessional element that sought to turn the self into discourse - a kind of narrative subjectivization that could not be achieved through surveillance alone. For Foucault (1987), confessional processes extend the objectifying and individualising effects of surveillance into an auditory form. By virtue of the relations of power, this specific practice induces forms of government and dominance that have the capacity to gain a hold over the subject not from above "but rather from below, as an act of obligatory speech" (Foucault, 1987, p.62).

In this sense the observations of other group members came to constitute a functional vocabulary from which a reflexive and indeed reformative narrative about the "self" (that is, a 
technology of the self) could be constructed. Moreover, the formation of the "truth" is not a matter of merely confessing one's innermost desires or sins. Rather it arises out of the relationship that is created between the confessor and the person to whom one confesses insofar as what is confessed requires a degree of interpretation and decipherment which Foucault referred to as "the method of interpretation". As such, the T-group juxtaposed two distinct yet interrelated disciplinary technologies that functioned, on the one hand, to make the individual "in" society more visible, observable and known while, on the other hand, to utilise information to form a reflexive narrative that enfolded them into powerful patterns of self-awareness and self-production.

The transformation of the self into discourse in which the speaking subject also becomes the subject of the statement unfolds within a certain kind of power relation. As Foucault (19787, p. 61) points out, "one does not confess without the presence (or virtual presence) of a partner who is not simply the interlocutor but the authority who requires the confession, prescribes it and appreciates it". Individuals are compelled to articulate the self to their superiors as it is they that are perceived as an authority capable of judging, punishing, forgiving and reconciling.

This also produces changes within the individual who articulates it, for as Foucault (1987, p. 63) argues, it "redeems, and purifies him; it unburdens him of his wrongs, liberates him and promises salvation". For the T-group members, it was the group itself that became an "authority" in its own right as it was the group that required of each member a confession. In this sense, it was the group itself then that prescribed it, appreciated it, punished, forgave and reconciled. 


\section{Corporate leadership training: The development of the T-group 1950-1970 and its place in industrial history}

The post-war period also brought into sharp focus a newfound awareness of how the performance of American manufacturing industry during the conflict was positively affected by management as a distinct economic practice. Before this time management was more an active and useful field of study than a global organising phenomenon. The concept of management became an integral part of a large scale programme to aid European economics with pecuniary support for the US in order to prevent the spread of Soviet communism known as the Marshall Plan (officially the European Recovery Program). This initiative was in operation for four years beginning in April 1948 and marked a significant attempt by both the United States and Britain to mobilise "management" for social and economic reconstruction. This resulted in what became known as the management boom and provided a catalyst for the rapid proliferation of management theory and practice within not only industrially developed countries such as the United States and Britain but also developing nations such as India, Brazil and southeast Asia (Drucker, 1973).

Unsurprisingly it was not long before the T-Group found a receptive audience in the economic domain. Pecuniary matters necessitated that the NTL should move into the lucrative business of management, leadership development and executive training because by 1954 a grant provided by the Carnegie Institute had all but run out (Bradford, 1974). Typically T-Group participants tended to be teachers, social-workers and clergy but, in 1956, the first homogeneous group of business executives was organised in an attempt to utilise T-group education in corporate leadership training and development. It seemed at the time that managers were not only expected to understand and utilise the psychological forces that motivated those they supervised but also their own modes of inter-personal behaviour and relations (Rose, 1999). 
As House (1967) noted, shortly after T-group education emerged, several graduate schools of business included at least one course dedicated to T-group education and practice as part of their syllabus. By the 1960s, the NTL and its trainers were well and truly established, enjoying endorsements from prominent thinkers in the field of psychology such as Abraham Maslow and Carl Rogers. By 1966 at least 20,000 business executives from organisations including Kodak and IBM were purported to have benefited from the T-Group experience and the learning methods the NTL had to offer (Highhouse, 2002). This level of sustained attention also meant that the TGroup movement received a considerable amount of criticism from several sceptical commentators, the most prominent of which was George Odiorne $(1962,1963)$. Moreover, many large organisations in different countries were beginning to introduce in-house laboratories (House, 1967).

In 1961, based on the results of empirical enquiries conducted by the University of California, Los Angeles (UCLA) Human Relations Research Group, Tannenbaum, Weschler, and Massarik (1961) reported that the claims pertaining to the social value and effectiveness of T-Group training were somewhat mixed. Odiorne $(1962,1963)$ also lamented that claims about the effectiveness of the T-Groups lacked adequate support and that such practices often created potentially psychologically damaging situations that in some instances got out of hand, as it were. As criticisms of the T-Groups increased in intensity, several accounts emerged that highlighted the darker side of the intense emotional experiences elicited by the experiential method. Poppy (1968; cited in Highhouse, 2002, p. 285) reported one particular session where a chief executive personally disclosed to the other members of the group that he had physically abused his wife, recounting that, "I started shaking her, but my right hand slipped as I pushed her back and forth, and smashed her in the throat".

As the T-group become ever more popular, this kind of confession-like encounter became more symptomatic of the kind of quasi-therapeutic environment that the practice evoked. As an educational process, the T-group incorporated the classic Foucauldian "principle of latency" 
(Foucault, 1987) insofar as the laboratory method itself was primarily concerned with not only what the individual in the organisation wished to hide but also that which remained "hidden from himself' (Foucault, 19787, p. 66). Here, it was the task of other group members to observe each other, to judge them and provide them with a more realistic perception of how their behaviour impacted on others.

\section{Toward a modern-day form of multi-rater/source assessment: The emergence of 360 - degree feedback in the 1980s-2000s}

According to several authors (Edwards \& Ewen, 1996), the genesis of modern day multirater/source assessment and feedback systems can be traced back to a gradual coming together of existing organisational appraisal and development mechanisms such as employee satisfaction surveys, peer evaluations, assessment centres and team-based appraisal. Authors such as Hollenbecker (1996) and Highhouse (2002) have pointed out that there are distinct educational undertones present within the current multi-rater/source feedback mechanism of 360 that share many of the fundamental assumptions that underpinned the educational movement of the laboratory method and its flagship method of education, the T-Group.

By the 1970s, in the US, the human relations paradigm began to inform work on organisational change under the name of organisational development (hereby referred to simply as OD). Although rebranded in order to appeal to a new kind of economic market, those triedand-tested methods developed by the NTL a decade earlier (namely, the T-group method) were still being used intensively by OD practitioners in the form of "team-building" (Hollway, 1991).

Around the time that the T-Group began to increase in popularity within the economic domain generally and OD specifically, several large corporations were beginning to experiment with multi-rater/source observation and feedback. In 1959 the Esso (the international trade name of ExxonMobil) Research and Engineering Company designed and implemented a 
programme aimed at facilitating the individual self-development of Esso managers. The programme, known as 'rate your supervisor', was designed to provide managers with a heightened awareness of the strengths and weaknesses of their managerial technique that would facilitate their professional self-development. Each supervisor was to be provided with a personalised report that detailed how they were perceived by their subordinates on a range of pre-determined competencies, some of which were of a personal nature relating directly to the supervisor's personal demeanour, moral integrity, interpersonal manner and aspects of their personality. It was believed that, subsequent to being provided with this performance-related feedback, supervisors would actively seek to rectify weaknesses, taking whatever action necessary to achieve self-development. The entire process was underpinned by the maxim, "all development is self-development":

Elements of this self-development tool created by the Esso Research group and the assumptions that underpinned its theoretical standpoint closely resemble those of the more recent 360-degree feedback instrument which has as its central idea the use of feedback data gathered from multiple sources to enhance performance and aid development (Hollenbecker, 1997). The development tool itself comprised four checklists which incorporated a broad range of personal traits, job-related behaviours and management techniques. These items were divided into three distinct categories: personal traits, results and method. Each checklist contained various items that included "a good technical man", "tactful”, "indecisive", "considerate", "honest", "stubborn", "too conservative", "immature", "fair", "lacks a back bone" and "is aggressive" (Maloney \& Hinrichs, 1959).

The emergence of the contemporary human resource practice that has become colloquially known as 360 is popularly believed to have occurred during the late 1980s and early 1990s. During this time only a handful of organisations were beginning to experiment with this kind of organisational tool, mainly for developmental purposes (Bracken, 1994; Edwards \& Ewen, 1996; Toegel \& Conger, 2003). In the mid-1980s, several well-known US companies such as Disney 
and Nestle were utilising multi-rater/source feedback for leadership development and performance appraisal (Edwards \& Ewen, 1996). Before this time, a number of large corporations including Gulf Oil and United Airlines were purported to have used multirater/source feedback mechanisms as a measure of leadership effectiveness.

By the late 1990s, organisational trends driven by the United States' desire to compete in a global economic market and shifts in the socio-economic climate meant that traditional (topdown) employee appraisal systems had become increasingly difficult to implement effectively, with many managers and supervisors finding themselves ill-placed to undertake such review processes due to various considerations including the sheer number of employees under their supervision (Hollenbecker, 1997).

In 1990, London, Wohlers and Gallagher provided an interesting case example of how many managers at this time were seeking, "input from their co-workers (their subordinates and their peers) to identify ways to improve their performance" (p. 17). According to London et al. (1990, p. 17):

"A survey is designed containing items that are important elements of leadership and interpersonal relationships in the organisation. Managers are rated on the survey by their subordinates, peers, and supervisors. The managers also provide self-ratings”

As of the late 1990s, multi-rater/source observation and feedback mechanisms have been increasingly used in conjunction with employee appraisal programmes and, as such, more in line with their original purpose as a vehicle of employee training, development and ultimately betterment (Fletcher, Baldry \& Cunningham-Snell, 1998). Within the private sector, the adoption of multi-source assessment methodology like 360 was not widespread in its application until the 1980s and early 1990s (Edwards \& Ewen, 1996). This was due in part to the way in which organisations were structured and governed during this time. The application of 360 as a specific 
type of individual evaluation and development instrument was rare prior to the 1980s. Although 360 never really took off until the 1990s, in recent years both its scale and scope have expanded beyond its initial application as a source for manager development insofar as it has gradually come to replace or rather supplement traditional forms of management and employee appraisal (Maylett, 2009; Toegel \& Conger, 2003). At the level of the organisation, 360 (and multirater/source feedback mechanisms generally) finds favour in its capacity to align individual behaviour with corporate values and organisational ideals (Edward \& Ewen, 1996). At the more micro-functional level of the individual, the (multiple) subjective performance feedback is believed to lead to self-development by way of self-awareness and self-knowledge about one's workplace performance and behaviour (Ermongkonchai, 2008). This kind of micro-functionality is expressed in terms of the development and learning potential it generates.

Contemporary 360 observation and feedback mechanisms are designed to impel the individual at work into a network of observation and feedback relations that encourage reflexive practices regarding the self and perceptions thereof (McDowell \& Cruz, 2008). This reflective process is, like that incited by the T-group, characterised by an open dialogue that seeks to compare self/other perception so that a "more realistic" picture of individual performance and leadership emerges. Characteristic of the kind of observatory mechanisms utilised by the Tgroup method, we contend that 360 operates as a kind of "inverted" panoptic technology that organises individuals by way of a distinct kind of human surveillance network that functions to observe and document an individual's work-based performance and behaviour.

According to Foucault (1977, p.206) the, "panoptic schema makes any apparatus of power more intense: it assures its economy... its efficiency" to the extent that disciplinary power cannot be exercised in the absence of a form of omnipresent surveillance capable of making visible all those on whom its gaze is fixed. The manner in which current 360 practices are organized and utilised by organisations is very much centred around this apparatus of power insofar as the individual under scrutiny is placed, metaphorically speaking, at the centre of a circle of multiple 
sources of observation (and hence surveillance) geared toward the assessment of their workbased conduct, behaviour and performance, standing tall for all to see, to judge, and to normalise. In a sense, they "stand at the centre of a circle of feedback sources. These sources are the people who know you best. They are the people whose opinions you trust; at work, at home, and in the community" (Bracken et al., 1997, p. ix). Each observer (or gaze) then forms a part of the overall functioning of a form of power bent on the observation and hence, the control of conduct.

Panoptic power, for Foucault (1977), represents a specific type of distribution of individuals in relation to one another. In light of this we suggest that 360 is representative of a disciplinary practice that organises space not through the architectural arrangement of walls, partitions and ceilings or through the structure of the organisation in terms of hierarchy, tasks or the specification of offices but through the strategic assembly and social arrangement of bodies in space. Modern disciplinary power and governance at work in this sense does not assume a hierarchical, architectural or structural form. Rather it is a distinct form of social organisation that arranges individuals in such a way as to instill within them the sentiment of omnipresent visibility (that is, control through observation), compares these observations against a prescribed norm/standard and places them within relations of observation and signification. These relations function to penetrate their behaviour, thus rendering them objects of knowledge and as a result amenable to reformation.

According to McDowell and Kruz (2008), the majority of 360 processes begin with the reflexive practice of self-assessment/rating as judged against pre-determined performance criteria. A case in point is exemplified by the 360 feedback mechanism developed by the INSEAD Global Leadership Centre (Kets De Vries, Vignaud, Treacy, \& Korotov, 2007) which has been designed specifically to encourage introspection which is believed to lead to selfdevelopment and active behavioural change. It is well known that many proponents of 360 (for example, Tornow, 1993; Yammarino \& Atwater, 1993) believe that at the core of multi- 
rater/source feedback methodology is a cognitive process of self-reflection which is presumed to enhance individual self-awareness.

In the same vein as the T-group the modern multi-rater/source feedback mechanism of 360 constitutes an interactive process that takes place at the level of individuals' personal and interpersonal relations insofar as (in addition to the individuals themselves) an assembly of significant others are providing their observations and interpretations (that is, feedback) of jobrelated performance and behaviours analogous to what Foucault (1987) might recognise as a testimony of witnesses. Foucault (1996) documents how knowledge was transmitted and authenticated in the late middles ages through the ritual of dispute. This consisted of a verbal confrontation between two adversaries that relied on the rhetoric of authority rather than truth. The more witnesses of authority, strength and influence an individual had on their side the greater their chances of victory. Within the confines of the T-group and 360 it is the group that constitutes the common voice of authority whose knowledge is authenticated through the ritual of consensus.

Just as the T-group provided a method for turning individual thought and action into a manageable vocabulary, the contemporary practice of 360 also encompasses a quasi-confessional element insofar as it actively incorporates a self-reflexive practice that turn the self at work into an "autobiographical narrative" (Foucault, 1987, p. 62) which can be documented and used for the purposes of appraisal and development. In this sense the "self" becomes materialised in terms of an open dialogue on the part of both the observer/observers and the individual themselves. Within the development of 360 mechanisms and practices, it becomes no longer a question of simply saying what is lacking with regards to an individual's work-based performance and behaviour. Rather 360 processes encompass the functional act of developing and rehabilitating individuals toward a new way of being by appealing to a moral imperative to change for their own personal betterment. 
As was the case with the T-group, the practice of 360 involves the classic Foucauldian "principle of latency" expressed in terms of the discrepancies that exist between an individual's "self" perception and evaluation of their own performance and behaviour at work and those of the multiple observations provided by others. These aspects of the self, however, do not remain hidden: rather what 360 does is take the concept of the "self" that the individual has already constructed and compare this with a more realistic or truthful interpretation born out of the observations and interpretations of others - a kind of common consensus about the self that is believed to provide the individual with a more accurate picture of who they are at work. It is by way of the "method of interpretation" (Foucault, 1987) that the work of producing and validating the truth about the self on the basis of decipherment is achieved. This is most apparent in that the truth does not reside solely within the subject alone as such things are bound to the relationship that is created between the individual who is believed to be, in a sense, partially "blind" to the "truth", and the organisation in which they are embedded - as it is only they that is, the organisation - that are capable of recording, deciphering, and verifying what constitutes truth.

In a study of the operations of power in psychodynamic psychotherapy, Hook (2001b) noted that during therapy sessions individuals were more than willing to offer explicit self-evaluations in the form of therapeutic narratives and self-evaluations. Patients were said to have often engaged in open dialogues in the form of problem-focused self-narratives that were predominantly reflexive in nature. In this sense, the therapeutic objective actively constituted this kind of quasi-therapeutic narrative in which the individual assumed the position of both the therapist and patient. As such, the psychotherapeutic session or mechanism itself formed a kind of technology of the self in which the patient is called upon to identify themselves as a certain type of subject - as symbolised by narratives about the self within a psychotherapeutic context. As a consequence, the therapeutic objective itself became the subjectivization of the patient as they were effectively placed within a network of power relations that encouraged explicit forms 
of self-evaluation - that is, the self-regulatory capacities of the subject as they took responsibility for their own diagnosis and therapy.

In the same vein, the innovation of the T-Group created an educational technology that organised individuals into a kind of problem-focused learning community that functioned to enfold them into a specific type of inter-personal self-learning and self-regulation. In this case the social organisation of individuals into a kind of quasi-therapeutic group became a vessel through which the T-group educators could appeal to individual agency, to their own personal desire and moral responsibility to change and to develop as a person and as a citizen. The subjectivization of the learner was achieved therefore through the problematisation of specific behaviours and the implementation of a technical assembly of technologies/techniques that prompt the selfregulatory capacities of the subject who is now responsible for their own self-development.

Just as the T-group became a vehicle for self-understanding within a group context, the contemporary practice of 360 expands upon and develops the idea of individual or self reeducation by way of multiple observation and feedback by placing these concepts and the disciplinary effects they presuppose within an organisational context. The road to selfdevelopment and consequently self-government is thus traversed in the same way - that is, through a self-awareness and self-knowledge about one's "self" at work that is facilitated by the reflexive mechanisms and practices provided by the 360 process. The invocation of a programme focused on the development of individuals acts as a means of subjecting them to (and as a result making them more perceptible to) the goal of self-development. By taking up the goal of self-development, individuals are essentially rendering themselves governable. 


\section{The governing of the self/the self-governing self: Psychology, power and subjectification}

at work.

We have made the case that within contemporary work and organisational life there has emerged a form of government that mobilises and operationalizes the para-psychological entity of the "self' in such a way as to render the individual at work capable of developing and, as a result, governing themselves. The process of self-development refers here to the inscription of material effects (that is the technologies/techniques of objection and subjection) on the body by a series of psychological knowledges and practices that over historical time have functioned to produce individual that are capable of developing, and as a result governing themselves.

Such a contention problematises and destabilises those emancipatory aspects of the "new work order" (Gee, Hull \& Lankshear, 1996) that see employees as liberated from the bureaucratic rationalisation of Weber's proverbial iron cage and "empowered" to manage their own behaviour and their own risk through continuous self-development. We propose that the desired end to which this specific relation of power is put to purpose is a subtle form of selfgovernment that operates under the rubric of self-development.

According to Dean (2010; see also Hook 2007) government can be divided into three interlocking domains: those of the state, of the person and of the self. Similarly, he defines government as the "calculated direction of human conduct" (Dean, 1999, p. 198). This is seen as including not only physical activities but also "self-referential qualities" such as reflexivity, selfattentiveness and self-awareness - what Hook (2007, p. 243) refers to as the "stuff of psychology" in which the self acts upon the self by way of technologies/techniques of self. In light of this, we have presented an alternative conceptualisation of 360 that seeks to go beyond thinking about this specific human resource practice in purely functional terms and we propose that, within the mechanism of 360 , contemporary organisations are combining psychological knowledge and expertise with disciplinary practices. In so doing, they are extending 
governmental control within the organisation to include the self-governing capacities of the individual at work.

This form of government simultaneously targets, relies upon, and ultimately (re)produces the "stuff of psychology" in terms of those multifarious aspects of the self such as abilities, aspirations, attitudes and behaviours. As Hook (2007) contends, the real-world application of psychological knowledge produces reality-effects as individuals come to subjectively experience themselves in terms of a psychologised self that can be known, understood and developed. The widespread diffusion of psychological knowledge and expertise within the domain of contemporary work organisation has then not only provided the modern economic agent with a symbolic framework for understanding themselves but also with a means of regulating and governing themselves.

When viewed within the framework of governmentality, both the T-group and 360 share many features with what Cruikshank (1999) has termed "technologies of citizenship". Technologies of citizenship operate according to a specific rationality of government that seeks to actively promote individual autonomy, empowerment, self-sufficiency and political engagement as a means of individual subjection. In this sense they engage subjects as active agents, free citizens, as members of self-managing communities or organisations who are responsible for taking control of their own risks.

For Dean (2010, p. 197), technologies of citizenship are deployed in an attempt to enhance the agency of what he calls "target populations" (for example, victims of crime or smokers) enabling them to alter their status from "high risk" individuals to "active citizens". Here, those individuals belonging to a target population enter into an agreement whereby they subject themselves to technologies of agency (of which technologies of citizenship constitute but one instance) under the rubric of empowerment and, in so doing, seemingly enfold themselves into "a range of normalizing, therapeutic and training measures designed to empower them, enhance their self-esteem, optimize their skills". 
In many ways this is precisely what both the T-group movement and current 360 practices have sought to do. For the laboratory method of education, the target population constituted those individuals, groups and/or communities considered at risk of social and civil disharmony within the United States at the time. Within the current economic climate, individuals are constantly at risk - of unemployment, organisational change, global economic developments and technological advances. Yet it is not solely the responsibility of the organisation to manage this risk. Rather it is the individual who is seen as primarily in charge of taking control of their own learning, their own development and their own employability - that is, managing their own risk.

In this sense 360 is emblematic of a technology of agency in that it may well provide a means of empowering individuals by giving them a voice and educating them as to their personal and professional deficiencies at work. In doing so, it also provides those many and varied forms of authority (of which organisations are but one) with the means of enacting a form of government that relies for its effectiveness on the self-regulating and self-governing capacities of the individual. Correspondingly, according to Dean (2010, p.200) modern non-authoritarian style regimes of government have become characteristically "more multiple, diffuse, facilitative and empowering", yet in the same vein, "more disciplinary, stringent and punitive".

In light of this contention it comes as no surprise that several authors are less than optimistic about the emancipatory rhetoric currently circulating within contemporary organisational literature regarding the apparent decline of bureaucracy as the dominant form of work organisation. In their analysis of what they refer to as the "new work order", Gee et al. (1996) detail their skepticism surrounding claims of workplace democracy and empowerment, suggesting that such discourses may in actuality serve to conceal new "linguistic techniques of control that are masquerading in the name of democratic organisational reform across the globe" (p. 19). The invocation of democratic discourses within the workplace is then, according to Gee et al. (1996), as much about the creation of new social (and organisational) identities for the purpose of control and governance than about democracy and empowerment. 
Political scholars such as Cruikshank (1999) have also posited that those democratic discourses surrounding citizenship, self-government and empowerment are themselves just as much a measure of individual subjection and government than a legitimate political solution to socio-political problems. Although the present paper adds to this critical discussion, the extent to which the individual is either empowered or controlled by the institutions concerned with the conduct of conduct remains (and will continue to be) a much debated issue. The paradoxical nature of empowerment and oppression is such that certain strategies of government may in one sense function to empower and emancipate certain individuals or groups within society while simultaneously disempowering and oppressing others. The same can be said for any new regime of subjection in that potentially oppressive forms of government that may favour one group over another bring with them new possibilities for action in the form of resistance.

The historical analysis presented in this paper brings into sharp focus the need for a greater awareness of the operations of power at the micro-functional/political level within contemporary organisations. In line with Hook (2001a, 2005, 2007) and Rose (1996, 1999), we believe that such a focus cannot be adequately grasped when the linguistic and/or textual aspects of discourse are prioritised over and above the material and the historical. This said, however, the genealogical method itself is not without limitation for as Foucault himself notes, "Whereas the interpreter is obliged to go to the depth of things, like an excavator, the moment of... [genealogy] is like an overview, from higher and higher up, which allows the depth to be laid out in front of him in a more and more profound visibility" (cited in Dreyfus \& Rabinow, 1982, p. 106-107).

The eminent "overview" genealogy in many ways constitutes a one-sided view of subjection as it attends primarily to the perspective of the institution and fails to consider "other" perspectives, such as those of the subjects of power for instance. Peter Dews (1987) has pointed to the fact that Foucault's analytics of disciplinarity are biased toward institutions and their representatives and thus neglect the "voice" of the subject being controlled. By focusing solely on the technical (material) formations by which individuals are subjected to power/knowledge, 
the "voice" of resistance is obscured to the extent that one is in many ways forced to revert back to a negative view that sees power as primarily repressive and devoid of the forms of resistance it is believed to produce. Genealogy then does not adequately grasp the multifarious operations of power and subjection in terms of resistance and counter-discourse - that is to say, the individual political action or rather counteraction that takes place within the positions subjects occupy "in" discourse.

It has been well debated that Foucault renders the performative quality of discourse somewhat restrictive by suggesting that subjects cannot actively or freely "make up" themselves outside those systems of symbolic significance that enfold them. When one considers the concepts of governmentality and subjectivization, however, a much less restrictive picture emerges: one that provides a degree of agency where "acting" individuals conduct themselves (Foucault, 1987, p. 26). For Foucault (1987, p. 20), even within rigid frameworks of subjection such as that of symmetrical congenial fidelity for instance, there are many ways to "practice austerity" and "many ways to be faithful". It is here then that individuals actively take on "doing" congenial fidelity and agentically personalise it. Despite the wealth of analytic techniques and methods Foucault's works provides, there is no strictly Foucauldian approach to the analysis of how individuals negotiate, resist, and personalise the positions they occupy in discourse (that is to say, subjectivization).

In closing, we urge that due consideration be given to the complexities and mutually reinforcing effects of the material and the discursive. In this regard, the operations of power/knowledge do not simply work through discourse to the extent that "discourse" itself becomes a mere effect of power. Rather, when the physical and material effects of power are considered in conjunction with the regimes of truth they function to reify and ratify, discourse becomes "both instrument and result of power" (Hook, 2001a, p. 33). From this perspective, discourse reinforces the material effects of power which in turn bestows upon those individuals that are subjected to it a "voice" through which to be heard. It is the latter aspect of this 
mutually reinforcing relationship that genealogy fails to address in any real substantive form. In short, as Hook's (2007) critique has pointed out those forms discourse analysis that focus solely on textuality fail to adequately grasp the relationship that exists between discourse and material reality. This in turn also constrains the extent to which such forms of analysis can theorise subjectivity on the basis of discourse alone. Although genealogy provides a crucial means of juxtaposing the discursive and the material - stepping outside of the 'text' if you like - it too cannot adequately theorise subjectivity on the basis of history alone.

Within the domain of psychology specifically one solution to this would be, we propose, to combine Foucault's genealogical framework with the more macro-oriented form of discourse analysis known as Critical Discursive Psychology (Wetherell \& Edley, 1999). This particular approach to the analysis of discourse accords well with Foucault's work as it attempts to synthesise discursive psychology's convergence on local pragmatics and the action orientation of language with Foucault's focus on the constitutive effects of power, knowledge, discourse, and ideology (Coyle, 2012). By combining discourse analytic endeavours with genealogy, one is provided with an approach to the analytics of power that is both materially grounded and historically contextualised. In this sense one can consider how individuals are simultaneously positioned by and position themselves within discourse in light of the social, political, and historical conditions in which such discourses (and the technical assemblages that accompany them) have developed. 


\section{References}

Argyris, C. (1964). T-groups for organizational effectiveness. Harvard Business Review, 42(2), 60-74.

Back, K. W. (1972). Beyond words: The story of sensitivity training and the encounter movement. New York: Russell Sage Foundation.

Bracken, D. W., Timmereck, C. W., \& Church, A. H. (2001). The handbook of multisource feedback. San Francisco, CA: Jossey-Bass.

Bradford, L. P. (1974). National training laboratories: Its history, 1947-1970. Bethel, ME: NTL Institute for Applied Behavioral Science.

Bradford, L. P. (1976). The laboratory method: A historical perspective. Group \& Organization Studies, 1(4), 415-429.

Bradford, L. P., Gibb, J. R., \& Benne, K. D. (1964). T-Group Theory and the Laboratory Method. New York. Wiley \& Sons.

Coyle, A. (2012). Discourse analysis. In G.M. Breakwell, J.A. Smith \& D.B. Wright (Eds), Research methods in psychology (4th edn.) (pp.485-509). London: Sage.

Cruikshank, B. (1999). The Will to Empower: Democratic Citizenship and Other Subjects. New York: Cornell University Press.

Dean, M. (2010). Governmentality: Power and Rule in Modern Society (2nd ed.). London: Sage.

Dewey, J. (1916). Democracy and Education: An Introduction to the Philosophy of Education. New York: The Free Press.

Dews, P. (1987). Logistics of Disintegration: Post-Structuralist Thought and the Claims of Critical theory. London: Verso.

Dreyfus, H. L., \& Ranibow, P. (1982). Michel Foucault: Beyond Structuralism and Hermeneutics. London: The Harvester Press Limited.

Drucker, P. F. (1973). Management: Tasks, Responsibilities, Practices. London: Heinemann Du Gay, P. (1996). Consumption and Identity at Work. London: Sage. 
Du Gay, P. (1997). Organizing Identity: Making People up at Work. In P. Du Gay (Ed.). Production of Culture/Cultures of Production. (pp. 286-322). London: Sage.

Edwards, M. R., \& Ewen, A. (1996). 360 Feedback: The Powerful New Model for Employee Assessment \& Performance Improvement. New York: Amacom.

Ermongkonchai, P. (2008). An Evaluation of Multisource Feedback (MSF) for Managerial Development in Large-Size Manufacturing Companies in Thailand. Contemporary Management Research, 4(3), 189-218.

Fletcher, C., Baldry, C., \& Cunningham-Snell, N. (1998). The psychometric properties of 360 degree feedback: An empirical study and a cautionary tale. International Journal of Selection and Assessment, 6(1), 19-34.

Foucault, M. (1977). Discipline and Punishment: The Birth of the Modern Prison. London: Penguin Books.

Foucault, M. (1982). Afterword: The Subject and Power. In H. L. Dreyfus \& P. Ranibow (Eds.). Michel Foucault Beyond Structuralism and Hermeneutics (pp. 208-226). New York: Harvest Wheat sheaf.

Foucualt, M. (1987). The History of Sexuality Vol. 1. London: Penguin.

Foucault, M. (1988). Technologies of the Self. In, L. H. Martin, H. Gutman, \& P. H. Hutton (Eds.). Technologies of the Self: A Seminar with Michel Foucault (pp. 16-50). Massachusetts: The University of Massachusetts Press.

Foucault, M. (1996). Truth and Juridical Forms, Social Identities. Journal for the Study of Race, Nation and Culture, 2(3), 327-342.

Gee, J. P., Hull, G., \& Lankshear, C. (1996). New Work Order. Behind the Language of the New Capitalism. Sydney: Allen \& Unwin Pty Ltd.

Hall, S. (1997). The Work of Representation. In S. Hall (Ed.). Representation: Cultural Representation and Signifying Practices (13-75). London: Sage. 
Highhouse, S. (2002). A History of the T-Group and its early application in management development. Group Dynamics: Theory, Research, and Practice, 6(4), 277-290.

Hollenbecker, G. P. (1997). Preface. In D. W. Bracken, M. A. Dalton, R. A. Jako, C. D.

McCauley, \& V. A. Pollman. Should 360-degree Feedback be used only for Developmental Purposes? (pp. ix-xii). Greensboro, NC: Centre for Creative Leadership.

Hollway, W. (1991). Work Psychology and Organizational Behaviour: Managing the Individual at Work. London: Sage Publications Ltd.

Hook, D. (2001a). Discourse, knowledge, materiality, history: Foucault and discourse analysis. Theory and Psychology, 11(4). 521-547.

Hook, D. (2001b). Therapeutic discourses, co-construction, interpellation, role-induction: Psychotherapy as iatrogenic treatment modality? The International journal of Psychotherapy, 6(1), 47-66.

Hook, D. (2005). Genealogy, discourse, 'effective history': Foucault and the work of critique. Qualitative Research in Psychology, 2(1), 3-13.

Hook, D. (2007). Foucault, Psychology and the Analytics of Power. Basingstoke: Palgrave Macmillan. Hook, D., \& Howarth, C. (2005). Future directions fo a critical social psychology of racisms/antiracism. Journal of Community \& Applied Social Psychology, 15(6), 506-512.

House, R. J. (1967). T-group education and leadership effectiveness: A review of the empiric literature and a critical evaluation. Personnel Psychology, 20(1),1-32.

Kets De Vries, M. F., Vignaud, P., Treacy, E. F., \& Korotov, K. (2007). INSEAD Global Leadership Centre 360-Degree Feedback Instrument: An Overview. In M. F. Kets De Vries, P. Vignaud, E. F. Treacy \& K Korotov (Eds.). Coach and Coach: The Psychology of Making Better Leaders (pp. 2-28). London: Palgrave.

Knights, D., \& Willmott, H. (1989). Power and subjectivity at work: From degradation to Subjugation in social relations. Sociology, 23(4), 535-558. 
Lakin, M. (1972). Interpersonal Encounters: Theory and Practice in Sensitivity Training. New York: McGraw-Hill.

Lippitt, R. (1949). Training in Community Relations. New York: Harper Brothers.

London, M., Wohlers, A. J., \& Gallagher, P. (1990). A feedback approach to management development. Journal of Management Development, 9(6), 17-31.

Maloney, P. W., \& Hinrichs, J. R. (1959). A New Tool for Supervisory Self-Development. Personnel, 36(1), 46-53.

Maylett, T. (2009). 360-degree feedback revisited: The transition from development to appraisal. Compensation and Benefits Review, 41(5), 52-59.

Mayo, E. (1933). The Human Problems of an Industrial Civilization. London: Macmillan.

McCormick, L. R. (1991). New American History Series: Public Life in Industrial America, 1877-1917. American Historical Association.

McDowall, A. \& Kurz, R. (2008). Effective Integration of 360 Degree Feedback into the Coaching Process, The Coaching Psychologist, 4(1), 7-19

McNay, L. (1994). Foucault: A Critical Introduction. Cambridge: Polity Press/Blackwell.

Miller, P., \& Rose, N. (1991). Governing Economic Life. Economy and Society, 19(1), 1-31.

Minaham, M. (2006). Working With Groups in Organizations. In B. B. Jones \& M. Brezzel (Eds.). The NTL Handbook of Organizational Development and Change: Principles, Practices, and Perspectives. San Francisco, CA: Pfeiffer.

Mumby, D. K., \& Sthol, C. (1991). Power and discourse in organizations studies: Absence and the dialectic of control. Discourse \& Society, 2(3), 313-332.

Odiorne, G. S. (1962). Managerial narcissism - The great self-development binge. Management of Personnel Quarterly, 1, 20-25.

Odiorne, G. S. (1963). The trouble with sensitivity training. Training Directors Journal, 17, 9-20.

Putnam, Robert D. (2000). Bowling Alone: The Collapse and Revival of American Community. New York: Simon \& Schuster. 
Rose, N. (1996). Inventing Ourselves: Psychology, Power, and Personbood. Cambridge: Cambridge University Press.

Rose, N. (1999). Governing the Soul: The Shaping of the Private Self (2nd ed.). London: Free Association Books.

Sofer, C. (1972). Organizations in Theory and Practice and Theory. London: Heineman Educational Books.

Tannenbaum, R., Weschler, I. R., \& Massarik, F. (1961). Leadership and Organization: A Behavioural Science Approach. New York: McGraw Hill.

Toegel, G., \& Conger, J. A. (2003). 360-Degree Assessment: Time for Reinvention. Los Angeles, CA: Center for Effective Organizations Publication.

Tonrow, W. W. (1993). Editor's Notes: Introduction to Special Issue on 360-Degree Feedback. Human Resource Management 32(2), 211-219.

Townley, B. (1993). Foucault, power/knowledge, and its relevance for human resource management. Academy of Management Review, 18(3), 518-545.

Townley, B. (1994). Reframing Human Resource Management: Power, Ethics and the Subject at Work. London: Sage.

Wetherell, M., \& Edley, N. (1999). Negotiating Hegemonic Masculinity: Imaginary Positions and Psycho-Discursive Practices. Feminism and Psychology.

Willmott, H. (1993). Strength is ignorance; slavery is freedom: Managing culture in modern organizations. Journal of Management Studies, 30(4), 515-550.

Yammarino, F. J., \& Atwater, L. E. (1993). Understanding self-perception accuracy: Implications for human resource management. Human Resource Management, 33(2\&3), 231-247. 